\title{
ResearchArticle
}

\section{Analysis of combining ability in white seeded genotypes of maize (Zea mays L.)}

\author{
P.P. SHARMA, MUKESH VYAS AND S.P. SHARMA
}

\begin{abstract}
SUMMARY
The present investigation consisted of 45 hybrids alongwith 18 parents and four checks viz., Arawali Makka-1, Mahi Kanchan, Navjot and PEHM-2 a total 67 entries was conduted during Kharif 2002 in Randomised Block Design having three replications. The data were recorded on fourteen traits to study general and specific combining ability effects. In general inbred lines $\mathrm{L}_{1}, \mathrm{~L}_{3}, \mathrm{~L}_{11}$ and $\mathrm{L}_{15}$ were considered good general combiner for yield and yield contributing traits as well as for quality traits. Among the testers, the tester $\mathrm{T}_{2}$ was considered good general combiner for maturity traits, plant type traits, harvest index and starch content. Majority of the hybrids exhibited significant positive values for yield and yield contributing traits as well as quality traits. Thereby, indicating that for these traits the genes with positive effects were dominent. The variance due to lines was of greater magnitude than that of testers for most of the traits. The ratio of $6^{2} \mathrm{sca} / 6^{2} \mathrm{gca}$ indicated prependerance of non-additive variance for most of the traits. Parental lines $\mathrm{L}_{1}, \mathrm{~L}_{3}, \mathrm{~L}_{11}$ and $\mathrm{L}_{15}$ were found to be good general combiners for grain yield per plant as well as for other traits. Hybrid $\mathrm{L}_{12} \times \mathrm{T}_{1}$ exhibited maximum significant positive sca effects for grain yield per plant. While the hybrid $\mathrm{L}_{2} \times \mathrm{T}_{1}$ exhibited highest estimates of significant positive sca effects for starch content. In general, there is a close association between sca effects, relative heterosis and per se performance for grain yield per plant was observed among the best hybrid identified on the basis of sca effects.
\end{abstract}

Key Words : Maize (Zea mays L.), Single cross hybrid, Combining ability, Gene effects

How to cite this article : Sharma, P.P., Vyas, Mukesh and Sharma, S.P. (2015). Analysis of combining ability in white seeded genotypes of maize (Zea mays L.). Internat. J. Plant Sci., 10 (1): 80-84.

Article chronicle : Received : 01.10.2014; Revised : 03.12.2014; Accepted : 22.12.2014

\section{MEMBERS OF THE RESEARCH FORUM}

Author to be contacted :

P.P. SHARMA, Department of Plant Breeding and Genetics, Rajasthan College of Agriculture, Maharana Pratap University of Agriculture and Technology, UDAIPUR (RAJASTHAN) INDIA

Address of the Co-authors:

MUKESH VYAS AND S.P. SHARMA, Department of Plant Breeding and Genetics, Rajasthan College of Agriculture, Maharana Pratap University of Agriculture and Technology, UDAIPUR (RAJASTHAN) INDIA 